\title{
De Cicerone poeta - sine ira et studio
}

Katarzyna Marciniak, Pro Cicerone poeta. Poezja Marka Tulliusza Cycerona na przestrzeni stuleci, Instytut Badań Interdyscyplinarnych Artes Liberales, Uniwersytet Warszawski, Warszawa 2008, ss. 428.

PAWEL BLEJA / Poznań /

Powyższa książka trafiła ostatnio w moje ręce. Stanowi ona opracowanie nader obszerne, albowiem obok 368 stron samej rozprawy, nie sposób nie wspomnieć o imponującej bibliografii obejmującej ponad 1070 pozycji. Sięgnąłem do tej publikacji z ogromnym zaciekawieniem, ponieważ przez ostatnich kilka lat miałem przyjemność badać postać i pisma Cycerona w aspekcie dlań najistotniejszym, mianowicie w kwestii najwyższego dobra. Starałem się przy tym konfrontować twórczość filozoficzną Arpinaty z jego własnymi przeżyciami, wzlotami i upadkami, o których sporo wiemy z jego bogatej korespondencji. Dzięki niej możemy wszak wniknąć w osobowość Marka Tuliusza, poznając go nie tylko „z zewnątrz”, tj. od strony jego dzieł, ale także spoglądając niejako w jego wnętrze. Dla interpretacji filozoficznej i prawdziwego zgłębienia wyrażonych przezeń treści jest to źródło wprost nieocenione. W lekturze dzieł Cycerona nieraz natrafiamy na jego dumne usposobienie poetyckie zmieszane $z$ wątkami biograficznymi. Dzięki artykułowi Grażyny Witort pt. Marek Tuliusz Cyceron jako poeta (Meander, 1959, no 3, s. 150-160) dysponujemy pobieżną wiedzą na temat pewnej liczby zachowanych fragmentów, a także na temat oceny poetyckiej spuścizny po Marku z Arpinum. Brakowało wszelako właśnie szerszego i bardziej miarodajnego opracowania na ten temat.

Jakież jednak było moje zdziwienie i rozczarowanie, gdy okazało się, iż z obszernej rozprawy Katarzyny Marciniak nie mogłem dowiedzieć się niczego o samej poezji Cycerona! Spodziewałem się, że w książce tej znajdę należną dokumentację zdającą sprawę z jego talentu poetyckiego. Byłem przekonany, iż oprócz krytycznej edycji ocalałych fragmentów znajdę również adekwatne ich przekłady wraz z należnym komentarzem 
egzegetycznym, aby docenić z jednej strony hermeneutyczny wysiłek Autorki, a z drugiej Cycerońską poezję. Jak wiadomo z kilku wydań, nie zajmuje ona zbyt wiele miejsca (wszak jest to mniej niż 1oo heksametrów), a zatem przedłożenie ich polskiemu czytelnikowi nie wymagałoby aż takiego trudu. Tymczasem Autorka wzmiankuje jedynie marginalnie o wzorcowym wydaniu (Cicéron, Aratea, fragments poétiques, J. Soubrian (ed.), Paris 1972), które niknie w „monstrualnej” Bibliografii pod pozycją nr 913. Ponadto w ogromnej Bibliografii (w której niektóre pozycje widnieją chyba wyłącznie „od parady") zabrakło dwóch ważnych tematycznie polskich prac, mianowicie książki Mieczysława S. Popławskiego pt. Polityczna publicystyka w dobie Cezara i Augusta (Lublin 1935), która to świetnie przedstawia m.in. walory stylu i humor Marka Tuliusza, a także znakomitej monografii Jana Wikarjaka pod znamiennym tytułem Warsztat pisarski Cycerona (Poznań 1976), gdzie odnaleźć można należycie udokumentowane źródłowo rozważania na temat talentu i sztuki pisarskiej Arpinaty. Zupełnie nie jestem w stanie zrozumieć, dlaczego Autorka nie przedstawiła tak charakterystycznych poglądów Cycerona na twórczość poetycką i tzw. dziś krytykę literacką. Właśnie o tym traktuje także nowe opracowanie: A. Brzózka, Cyceron jako teoretyk i krytyk literacki, Kraków 2007 (nawiasem mówiąc, szkoda tylko, iż nie uwzględniono w nim własnej twórczości poetyckiej Marka Tuliusza).

Tym bardziej można było oczekiwać możliwości zapoznania się z ipsissima verba Ciceronis, skoro już pobieżny rzut oka na książkę Katarzyny Marciniak ukazuje erudycję autorki i jej znajomość języków obcych. Książka zawiera rozliczne i długie cytaty w języku greckim (antycznym), łacińskim, włoskim, niemieckim, angielskim, francuskim, które jednak nie zostały niestety przełożone na język polski. Można by zapytać w tym miejscu, dlaczego właściwie Autorka zdecydowała się pisać w naszym języku? Przytaczanie całych cytatów innych autorów świadczy o erudycji i znajomości języków obcych, wszelako nie czyni jednak książki twórczej i poznawczo przystępnej. Praca taka nie jest wszak egzegezą tekstów. Paradoksalnie więc książka o „Cyceronie poecie” nie zawiera materiału prymarnego dla rzetelnych rozważań i adekwatnej wykładni kwestii tytułowej. Jaka może być tu bowiem płaszczyzna komunikacji między autorem i odbiorcą? Sytuacja ta, pozwolę sobie na przyrównanie medyczne, kojarzy się z salą operacyjną: widzimy oto wielką ilość sprzętu i wykwalifikowany personel, lecz brakuje jednego elementu - pacjenta (choćby pod narkozą).

Jeżeli przed oczyma nie mamy zachowanych fragmentów poezji Cycerona, (jakiekolwiek by one nie były), to wówczas tracimy to, co może być wspólne w doświadczeniu i skazujemy się na subiektywne odczuwanie. Postać i twórczość, w tym przypadku poetycka, ulegają zmitologizowaniu, zwłaszcza gdy za obrońców bierze się Woltera, Kochanowskiego czy autorów powieści kryminalnych. W moim odczuciu Katarzyna Marciniak prezentuje postawę badaczki nazbyt emocjonalnie zaangażowanej. Przedstawia siebie jako obrońcę Marka Tuliusza Cycerona - co niebywałe - w konwencji procesu sądowego o zniesławienie. Sama nazywa siebie „advocatus diaboli”, który — jak pisze - broni „nie tyle przed licznymi krytykami jego poezji, ile przed pogardliwym spychaniem Cycerońskich wierszy na margines literackiego istnienia” (s. 18). Nie sposób nie odnieść przy tym wrażenia, iż nie potrafi ona wyjść poza dychotomiczny podział czytelników czy badaczy na „fanatyków, gotowych wynosić Arpinate pod niebiosa” i „obrazoburców, którzy odważą się go całkowicie potępić”. Takie podejście wydaje się w dzisiejszych czasach raczej naiwne, wysoce nieobiektywne $\mathrm{i}-\mathrm{w}$ ostatecznym rozrachunku - raczej zniechęcające. Zakłada ono bowiem chęć uczestnictwa w zgoła jednostronnym procesie. W moich własnych badaniach nad postacią i twórczością Cycerona staram się podejść do jego osoby, czynów i twórczości z jak największą samodyscypliną i z chłodnym spojrzeniem. Nie ma wszak nic „złego” czy „obrazoburczego” w próbie krytycznego spojrzenia na fakty, które przez wieki wpływały na rozwój intelektualny kultury europejskiej. W istocie rzeczy taka próba krytycznego spojrzenia jest nie tylko wyrazem postawy racjonalnej, ale także conditio sine qua non wszelkiego postępu w nauce.

Autorka na wstępie stwierdza, iż podejmuje „walkę z krzywdzącym Arpinatę stereotypem”, który głosił, iż Cyceron pisał kiepskie wiersze. Przez wieki wiersze Cycerona stanowiły obiekt kpin znawców łaciny i przedmiot żartobliwych uwag humanistów. Niestety nie zamieszczając ocalałych wersów, Autorka nie pozwala czytelnikowi na wyrobienie sobie własnego sądu. Należałoby na przykład przedstawić in extenso dłuższy fragment $\mathrm{z}$ drugiej księgi De consulatu suo, apologetycznego poematu Cycerona, w którym opiewa on swój konsulat i siebie samego. Arpinata zacytował go swoim piśmie De divinatione (ks. I 11-13). Lektura i ocena tych heksametrów mówi nam bardzo wiele o ich autorze. Można by tutaj przywołać słynny motyw „upadłego polityka” (z ekranizacji Polańskiego Autor widmo), który pragnie odzyskać utraconą niechybnie cześć i wpływy poprzez literackie wychwalanie własnych zasług. W pełni zgadzam się z autorką, że Cyceron to przede wszystkim polityk, mówca, pisarz i publicysta. Zaiste trudno nazwać go oryginalnym filozofem - znacznie lepiej będzie powiedzieć, iż był on raczej znawcą i popularyzatorem filozofii greckiej. Jakkolwiek był on bowiem także człowiekiem pióra, byłoby być może lepiej, gdyby poświęcił się wyłącznie służbie politycznej. Z drugiej strony dla kultury duchowej byłoby zapewne lepiej, gdyby jeszcze więcej zajmował się działalnością naukową i z natchnieniem poetyckim oddawał się Muzom. Tak czy owak pozostaje pytaniem, czy poezja mogła być tą dziedziną, w której mógł on realizować się najpełniej? Wszak patrząc na wielu innych słynnych pisarzy i poetów, trudno znaleźć takich, którzy w równym stopniu potrafiliby oczarować odbiorcę.

Tymczasem nasz Cyceron, w oczach Katarzyny Marciniak, jest poetą w służbie politycznej. Jest to chyba najgorsze połączenie, albowiem nie daje szans na obcowanie z pięknem i dziełem sztuki. Na stronie 13 czytamy: „Pragnę przywrócić wiersze Marka Tulliusza do korpusu jego tekstów dyskutowanych, z należytą powagą, w kontekście - ważnych także dzisiaj - starożytnych idei, politycznych poglądów, wizji świata i koncepcji człowieka. Więcej, pragnę nadać poezji Cycerona rangę, którą ta utraciła już na przełomie er: starej i nowej - rangę nie tylko dzieł literackich, ale i wydarzeń”. Zdaniem Autorki Cyceron posługiwał się własnymi wierszami jako swoistym „narzędziem w walkach politycznych" i wykorzystywał poezję do swojego życiowego projektu "stworzenia za pomocą literatury wizji republiki idealnej, którą przekazać można przy- 
szłym pokoleniom”. Pozostaje jednak pytanie, czy Cyceron faktycznie myślał wyłącznie o dobru ojczyzny, a nie wyłącznie o swoim. Wydaje się, iż należałoby sięgać do literatury antyku i do Cycerona, wszelako nie z nastawieniem idealizującym, tj. w sposób panegiryczny czy laudacyjny. Uznawanie Cycerona za wzór humanitas tudzież wzór poety zaangażowanego w budowanie doskonałego państwa musi budzić pewne zdziwienie i niedowierzanie. Nie chodzi tutaj o spychanie jego poezji na „margines literackiego istnienia”, tylko o rzetelne spojrzenie na tę postać oraz o zapytanie, czego ona może nas współcześnie nauczyć. Spróbujmy zajrzeć w jego prywatne listy! Cyceron w listach to człowiek słaby, upadły na duchu, pogrążony w smutku wywołanym tymi momentami życiowymi, które wystawily go na próbę. Konfrontując jego listy i pisma o charakterze filozoficznym, dostrzec można głęboką ambiwalencję, a nawet pewne rozdarcie między życiem duchowym a życiem publicznym. Już Petrarka stwierdził, że Cyceron z listów to inny Cyceron niż ten z pism i zapewne też poezji. W jego życiu istniał głęboki rozdźwięk (można tutaj nawet mówić o pewnej chwiejności czy obłudzie). Opinie innych pisarzy, nawet te skrajne, ukazują nam Cycerona jako prawdziwego człowieka z krwi i kości wraz ze wszystkimi jego słabościami oraz namiętnościami, nie zaś jako postać pomnikową, do której wołamy: „Święty Tuliuszu, uczyń nam ojczyznę szczęśliwą!”. Taki Cyceron wydaje się jednak zarazem nie tylko bardziej realistyczny, ale także interesujący i bardziej ludzki aniżeli Cyceron przesadnie wychwalany w swych poematach. Mierząc się z Cyceronem, należy zmierzyć się zarówno z jego poezją, jak i prozą; nie należy obawiać się narażenia na śmieszność. Taka byłaby moja odpowiedź na postawione na stronie 27 pytanie: „czy ktoś mógłby się mierzyć z Cyceronem-prozaikiem, nie narażając się na śmieszność?”. Jeżeli prawdą byłaby teza postawiona przez Katarzynę Marciniak (że mianowicie „najpoważniejszy błąd polega na odseparowaniu Cycerona-poety od Cycerona-polityka”), to można by odpowiedzieć, iż źle zdaje się to świadczyć o twórcy poezji, gdy ten zamiast służyć sztuce, wykorzystuje ją jedynie do osiągnięcia władzy. Znacznie bardziej „szlachetny" z punktu widzenia estetyki byłby Lukrecjusz, który w swym natchnionym poemacie krzewił filozofię Epikura. Wbrew pewnemu „zarozumialstwu” i ,arogancji” Cycerona-poety oraz twierdzeniu, że wpisuje się on w nurt kultury śródziemnomorskiej, należałoby raczej wskazać na to, że nawet najwięksi twórcy tej kultury zawsze mieli jednak coś do ukrycia. Właśnie dlatego Homer pozostaje taką zagadkową postacią podczas gdy Platon kryje się za wizerunkiem Sokratesa; podobnie Lukrecjusz czy Diogenes Laertios, o życiu których niczego nie wiemy.

Dlaczego mielibyśmy stawiać Cycerona na piedestale? Z pewnością należy chwalić Cycerona za jego wysiłek badawczy oraz za to, że w chwilach, gdy był on odsunięty od władzy, zajmował się adaptacją filozofii greckiej. Robił to wszak z wielkim rozmachem i wnikliwością, dokonując przekładów i twórczo komponując swoje dzieła z zakresu filozofii. Sam zresztą w swoim dziele $O$ wróżbiarstwie (II 1-2) wskazywał na cele, jakie mu przyświecały. Poprzez wydanie swych dzieł pragnął on bowiem pokazać obywatelom „drogi do najlepszych sztuk" (optimarum artium vias traderem meis civibus) oraz "pouczać i kształcić młodzież” (si docemus atque erudimus iuventutem). W istocie Cyceron starał się rzetelnie przybliżyć wartość filozofii greckiej. Abstrahując od znaczenia polityki w życiu Arpinaty, można zarazem spojrzeć na jego twórczość z perspektywy filozoficznej. Okaże się wówczas, że można odkryć Cycerona nie tylko akademicko-sceptycznego czy stoickiego, ale także - zwłaszcza w chwilach niedoli - epikurejskiego. Celem Katarzyny Marciniak, jak pisze ona na stronie 150, było „przywrócenie poezji Marka Tulliusza do korpusu jego tekstów, które zasługują na poważne potraktowanie”. Powyższe uwagi odnoszące się do jej książki należałoby potraktować jako pretekst do zastanowienia się nad pytaniem, co dla współczesnych może być szczególnie interesujacego w postaci Cycerona. Czy fakt, że był on poetą (nawet najzdolniejszym) w jakiś sposób wzbogaca nas, ludzi współczesnych? Czy fakt, że wykorzystywał swą poezję do walki politycznej, można uznać za jakąś uszlachetniającą cechę polityków? Osobiście nie chciałbym deklarować się ani jako „procyceronianista”, ani „antycyceronianista”. Z pewnością trudno byłoby mi odnaleźć się w takim (zaproponowanym przez Autorkę) dychotomicznym ujęciu twórczości Cycerona. Nie mogę również zgodzić się z ostatnim zdaniem książki Pro Cicerone Poeta: „Warto więc nadal kochać i nienawidzić Cycerona. Warto zacząć kochać i nienawidzić Cycerona-poetę" (s. 368). Miłość i nienawiść to motywy znane z poezji erotycznej. Poezji takiej nie uprawiał, niestety, nasz Marek Tuliusz. Szkoda, ponieważ wówczas takie natchnione przeżycie mogłoby uczynić go prawdziwym uczniem Muz. Wszelako w ujęciu historycznym powoływanie się na tak skrajne afekty nie wydaje się najtrafniejszą motywacją badawczą. Znacznie bardziej owocne byłoby tutaj ponad wszelką wątpliwość podejście sine ira et studio. 